\title{
PERANCANGAN ANTARMUKA GRAPH US SEBAGAI PEMETAAN BENGKEL DI KABUPATEN SLEMAN
}

\author{
Agustina Srirahayu $^{1)}$, Andrie Prajanueri Kristianto ${ }^{2)}$, \\ Deden Hardan Gutama ${ }^{3)}$, Nendy Akbar Rozaq ${ }^{4)}$, Rais Mahmudi ${ }^{5)}$ \\ ${ }^{1)}$ STMIK Duta Bangsa Surakarta \\ Jl. Bhayangkara No. 55 Surakarta, Telp(0271)719552 \\ ${ }^{2,3,4,5)}$ Magister Teknik Informatika STMIK AMIKOM Yogyakarta \\ Jl Ring road Utara, Condongcatur, Sleman, Yogyakarta 55281 \\ Email :agustina@stmikdb.ac.id ${ }^{1)}$,andrieprajanueri@gmail.com ${ }^{2}$, hardantrade@gmail.com ${ }^{3)}$, \\ ab.terate@gmail.com ${ }^{4)}$,mudiedajhart@gmail.com ${ }^{5)}$
}

\begin{abstract}
Abstrak
Informasi tentang bengkel sangat diperlukan apabila terjadi suatu masalah kerusakan kendaraan bermotor yang disebabkan oleh kecelakaan lalulintas. Bengkel terbagi secara spesifik menurut jenis kendaraan yang ditangani. Pada penelitian ini dibagi menjadi dua jenis bengkel, yaitu bengkel kendaraan sepeda motor dan bengkel mobil. Informasi tentang bengkel kendaraan masih sebatas pada situs online masing-masing dan sering kali tidak memberikan informasi tentang peta lokasi bengkel. Adanya antarmuka Graph Us Bengkel ini dapat digunakan untuk pemetaan bengkel di Kabupaten Sleman yang dapat digunakan untuk membantu pengendara yang mengalami kecelakaan dan menemukan masalah atau kerusakan pada kendaraan. Pengendara mendapatkan informasi tentang daftar bengkel menurut jenis spesifikasi kendaraan antara sepeda motor dan mobil, mendapatkan informasi tentang deskripsi lokasi, gambar bengkel dan jalur tercepat untuk dapat datang ke bengkel tersebut. Penelitian ini menyajikan tentang antarmuka Graph Us pemetaan bengkel di Kabupaten Sleman tentang solusi pengendara yang menagalami kecelakaan dan akan melakukan perbaikan kendaraan di bengkel terdekat yang dapat diakses melalui aplikasi Graph Us.
\end{abstract}

Kata kunci: Graph Us, interface, Kabupaten Sleman, bengkel

\section{Pendahuluan}

Setiap tahun kendaraan yang ada di Indonesia semakin bertambah. Menurut Kepala Korps Polisi Lalu Lintas (Kakorlantas) Polri Irjen Pol Agung Budi Maryoto, populasi kendaraan yang ada di seluruh bagian Nusantara mencapai 124.348.224 unit. Data tersebut di dapat dari pendaftaran registrasi kendaraan yang terhitung sampai bulan juli 2016. Setiap tahun, pertumbuhan kendaraan mencapai enam juta unit pertahun [1].

Karena meningkatnya pertumbuhan kendaraan yang ada di indonesia, hal ini dapat mengakibatkan meningkatnya pula angka kecelakaan. Lembaga kesehatan dunia dibawah naungan PBB (WHO) merilis The Global Report on Road Safety yang menampilkan angka kecelakaan lalu lintas yang terjadi sepanjang tahun di 180 negara. Faktanya Indonesia menempati urutan negara ketiga di Asia di bawah Tiongkok dan India dengan total 38.279 total kematian akibat kecelakaan lalu lintas di tahun 2015 [2]. Ini disebabkan banyaknya pengendara yang melakukan pelanggaran lalu lintas dan padatnya populasi kendaraan yang ada di Indonesia

Kondisi sarana transportasi di Kabupaten Sleman masih banyak yang harus dibenahi. Sebagian sarana transportasi dan sarana pendukung misalnya rambu lalulintas dan pemasangannya masih belum tepat. Kondisi rambu yang sudah usang dan rambu terhalang oleh pohon dan dahan yang mengganggu penglihatan pengendara. [3]

Kebutuhan masyarakat akan akses jalan yang semakin tinggi dan populasi kebadaraan bermotor yang semakin tinggi memungkinkan Kabupaten Bantul mengalami masalah pada kecelakaan kendaraan bermotor. Pada waktu kecelakaan kendaraan motor terjadi, pengendara mengalami masalah salah satunya kerusakan pada kendaraan. Kendaraan yang rusak harus diperbaikin di bengkel sesuai jenis kendaraannya, misal kendaraan sepeda motor harus diperbaiki di bengkel sepeda motor pula. Untuk melanjutkan kembali perjalanannya, pengendara harus melakukan perbaikan pada kendaraan dengan memasukan kendaraan pada bengkel. Pengendara masih kesulitan menemukan bengkel mana yang terdekat karena tidak ada gambaran daerah bengkel berada. Jarak terdekat dan akses jalan yang akan dilalui dari lokasi terjadinya kecelakaan menjadi kendala karena belum cukup informasi yang diketahui masyarakat tentang lokasi bengkel sesuai jenis kendaraan.

Dalam penelitian ini dilakukan studi literatur dengan 2 penelitian yang pernah dilakukan. Pemanfaatan GoogleMaps untuk pemetaan dan pencarian data PTN dibangun menggunakan bahasa pemrograman JavaScript ddengan format Data XML dan GoogleMaps yang dapat digunakan untuk mencari perguruan tinggi di Indonesia dengan implementasi database menggunakan oracle. 
Aplikasi ini dimanfaatkan untuk menampilkan informasi seputar perguruan tinggi negeri dan diperhatikan ketersediaan data terutama letak dan lokasi suatu PTN. [5]. Penelitian yang akan dikembangkan ini akan menampilkan pemetaan bengkel sepeda motor dan bengkel mobil pada saat pengendara mengalami masalah kecelakaan, pengguna menggunakan aplikasi yang dapat menampilkan lokasi bengkel yang terdaftar yang disimbolkan dengan marker. Perancangan aplikasi in menggunakan database MySQL dan bahasa pemrograman $P H P$ dan untuk informasi bengkel mengenai arah jalan dibuat dengan menggunakan Leaflet Routing Machine dan gambar peta didapat dari Library Javascript Khusus mapping, Leafletjs.

Studi Pemetaan Kota Menado menentukan titik koordinat data jalan yang didapat dari hasil survey dengan menggunakan alat GPS digambarkan berupa titik-titik yang disebut track berfungsi untuk merekam jalan secara otomatis. Dalam proses penggambaran peta kota dilakukan beberapa tahap dan dimulai dari mengkalibrasi alat GPS dan pengosongan memori sebelum melakukan survey sampai pada pengeditan penggambaran jaringan jalan dengan menggunakan software autoCAD 2008.[4] Penelitian yang akan dikembangkan bagi penggendara atau pengguna aplikasi menggunakan aplikasi berbasis mobile dengan mendaftarkan akun pada sistem. Pengguna dapat mengetahui jalan tercepat menuju ke bengkel yang ditandai dengan garis berwarna merah. Selain jalan tercepat, pengguna juga disajikan informasi mengenai bengkel mobil yang terdaftar mempunyai fasilitas mobil derek. Dengan semakin canggihnya teknologi saat ini, perancangan pemetaan bengkel di Kabupaten Sleman dengan menggunakan map pada sistem berbasis android yang bernama "Graph Us" yang dapat menampilkan gambaran peta bengkel sehingga penyajian informasi akan memudahkan masyarakat menemukan bengkel yang akan dituju.

\section{Pembahasan}

Penelitian dilakukan melalui beberapa tahapan yaitu pengumpulan sumber data, analisis kebutuhan sistem, perancangan basis data dan perancangan interface. Pengambilan data bengkel dilakukan dengan metode observasi dengan cara mengamati langsung objek penelitian yaitu bengkel dengan melakukan dokumentasi dan mengambil data koordinat bengkel. Selain itu peneliti juga melakukan studi pustaka pada jurnal ilmiah yang telah dipublikasi sebelumnya untuk menyamakan garis besar penelitian pemetaan bangkel solusi kerusakan akibat kecelakaan kendaraan bermotor.

\subsection{Pengumpulan Sumber Data}

Berdasarkan hasil wawancara yang dilakukan pada Kasat Lantas Sleman Yogyakarta didapatkan kesimpulan bahwa kecelakaan tahun 2016 paling banyak disebabkan oleh lampu sein dengan jumlah 489 kasus kecelakaan, batas kecepatan disebabkan oleh batas kecepatan dan lampu sejumlah 267 kasus. Berikut diagram jumlah kasus kecelakaan

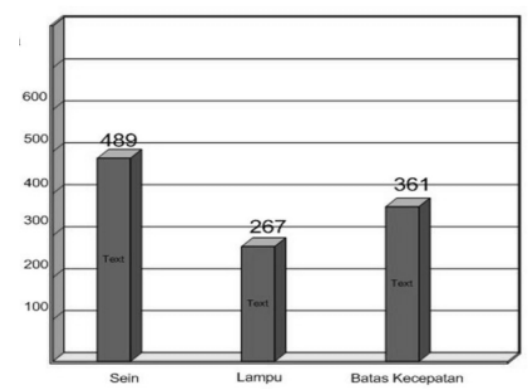

Gambar 1. Diagram Jumlah Kasus Kecelakaan

Dari gambar 1, kasus kecelakaan paling banyak disebabkan oleh lampu sein. Jumlah kasus kecelakaan yang besar menjadi penyebab rusaknya kendaraan bermotor yang akan melakukan perbaikan pada bengkel. Bengkel kendaraan pada penelitian ini dibedakan pada bengkel kendaraan sepeda motor dan bengkel kendaraan mobil.

\subsection{Analisis Kebutuhan Fungsional}

Analisis kebutuhan fungsional berisi informasi yang harus ada dan dihasilkan oleh sistem. Dibawah ini Tabel 1 tentang kebutuhan fungsional sistem.

Tabel 1. Kebutuhan Fungsional Sistem

\begin{tabular}{|c|l|}
\hline User & Kebutuhan Fungsional \\
\hline Admin & Login \\
\cline { 2 - 3 } & mengolah data bengkel \\
\hline Pengendara & $\begin{array}{l}\text { Dapat melihat peta lokasi } \\
\text { bengkel sepeda motor dan } \\
\text { bengkel mobil di Kabupaten } \\
\text { Sleman }\end{array}$ \\
\cline { 2 - 2 } & $\begin{array}{l}\text { Pengguna dapat memilih } \\
\text { marker bengkel di peta yang } \\
\text { menampilkan gambar } \\
\text { bengkel, nama bengkel dan } \\
\text { alamat }\end{array}$ \\
\cline { 2 - 2 } $\begin{array}{l}\text { Pengguna dapat melihat } \\
\text { inofrmasi arah jalan tercepat } \\
\text { menuju bengkel }\end{array}$ \\
\cline { 2 - 2 } & $\begin{array}{l}\text { Pengguna dapat melihat } \\
\text { informasi tentang bengkel di } \\
\text { Kabupaten Sleman }\end{array}$ \\
\hline
\end{tabular}

\subsection{Use Case Diagram}

User yang terlibat ada dua yaitu admin yang dapat login pada sistem dan mengolah data bengkel. User yang kedua adalah pengguna yang dapat melihat peta, memilih bengkel, melihat jalan tercepa menuju ke bengkel dan melihat infoemrasi bengkel di Kabupaten Sleman yang dibatasi 10 bengkel sepeda motor dan 10 bengkel mobil.

Usecase diagram pada sistem pemetaan bengkel merupakan gambaran keseluruhan aktifitas yang dilakukan oleh pengguna/aktor. Use case diagram ada 
aplikasi Graph Us pemetaan bengkel ini terlihat pada Gambar 1 sebagai berikut :

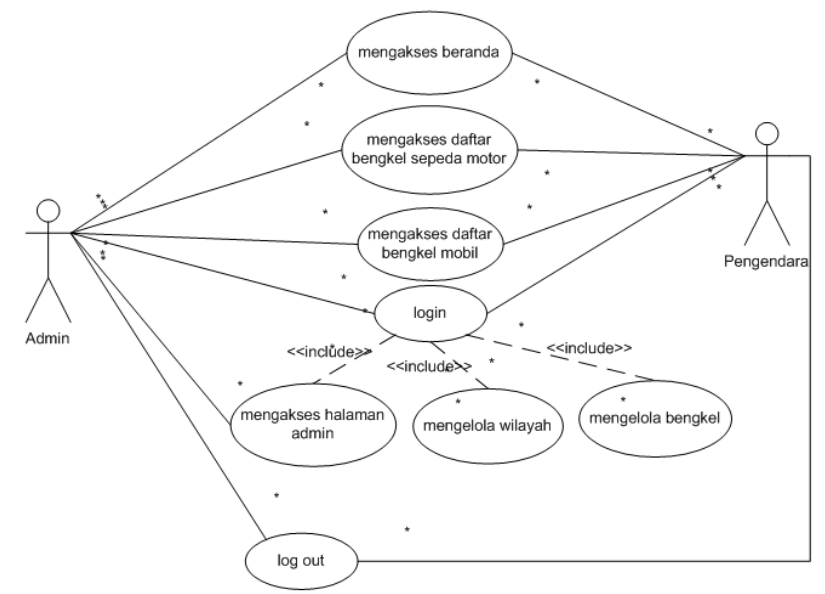

Gambar 2. Use Case Diagram Aplikasi Graph Us

Keterangan pada gambar 2, terdapat 2 aktor yaitu admin dan pengendara. Admin dapat mengakses beranda mengakses daftar bengkel, login ke sistem yang secara otomatis mengakses data admin, mengolah data bengkel dan data wilayah. Pengendara dapat melakukan akses ke beranda sistem, mengakses daftar bengkel sepeda motor dan mengakses daftar bengkel mobil.

\subsection{Perancangan Basis Data}

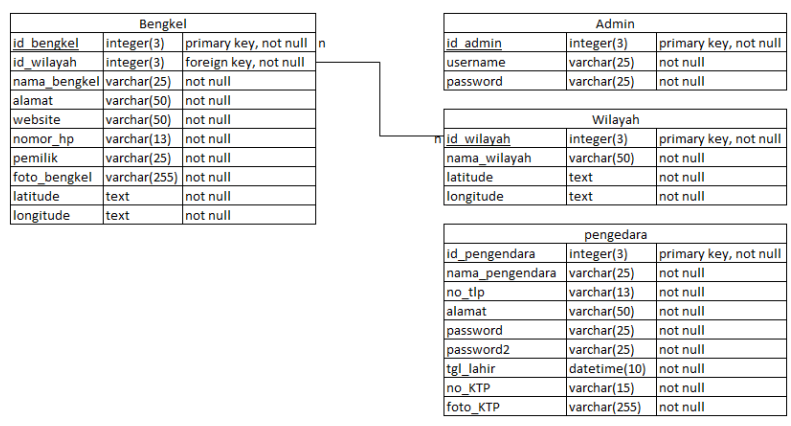

Gambar 3. Perancangan Database Aplikasi Graph Us

Gambar 3 diatas merupakan relasi antar tabel yang terdiri dati 4 tabel, yaitu tabel bengkel, tabel admin, tabel wilayah dan pengendara. Tabel bengkel memiliki hubungan many to many dengan tabel wilayah. Tabel bengkel menyimpan informasi tentang bengkel termasuk informasi lokasi bengkel, latitude dan longitude. Tabel admin untuk menyimpan informasi tentang admin pengguna sistem. Tabel wilayah untuk menyimpan informasi tentang wilayah dimana pengendara sedang mengakses aplikasi berada. Tabel pengendara menyimpan data pengendara.

\subsection{Antar Muka Pada Mobile}

Tampilan Interface Aplikasi Graph Us dengan pengguna sistem pengendara diimplemantasikan berbasis mobile sedangkan pengguna sistem admin diimplementasikan berbasis web. Tampilan login untuk pengguna pengendara kendaraan bermotor yang berbasis mobile seperti pada gambar 1 dibawah ini.

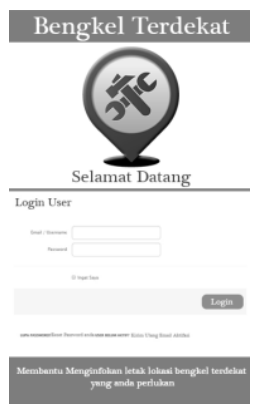

Gambar 4. Tampilan Login

Gambar 4 merupakan tampilan login pada saat aplikasi selesai diinstal. Sistem akan meminta pengguna kendaraan untuk mendaftarkan diri melalui menu profile yang akan dijelaskan pada gambar 6 tampilan menu profile pengguna. Pengguna sistem pengendara kendaraan bermotor dengan interface Beranda merupakan tampilan awal ketika aplikasi dijalankan. Terdapat beberapa menu antara lain :

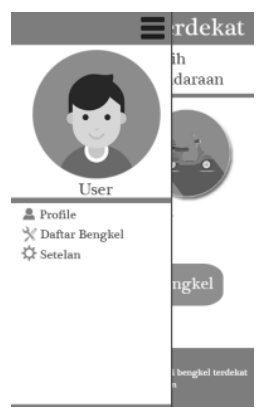

Gambar 5. Tampilan Beranda Menu Pengendara

Pada gambar 5, tampilan interface beranda dengan menu menampilkan profile dari pengendara, daftar bengkel antara lain bengkel mobil dan bengkel sepeda motor dan setelan. Apabila menu profile dipilih maka akan muncul tampilan pada Gambar 6 dibawah ini :

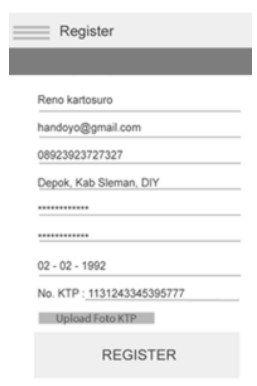

\section{Gambar 6. Tampilan Menu Profile Pengendara}

Pada Gambar 6, tampilan interface profile dengan inputan data diri untuk melakukan registrasi pengguna, data yang diinputkan antara lain nama, email, nomor hp, alamat, password, tanggal lahir, Nomor KTP, dan Gambar KTP. Ketika tombol registrasi dipilih maka akan muncul tampilan kode aktivasi seperti gambar 7 dibawah ini. 


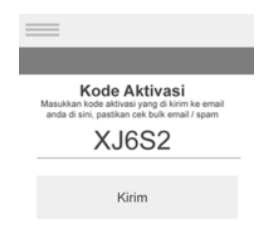

Gambar 7. Tampilan Kode aktivasi

Gambar 7, kode aktivasi ini dikirm melalui email ke profile dari pengguna pengendara yang melakukan regitrasi untuk verifikasi kebenaran data.

Menu Daftar Bengkel jika dipilih maka akan muncul tampilan sebagai berikut seperti pada Gambar 8 .

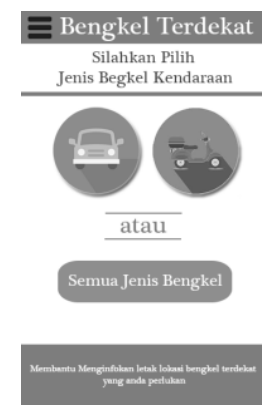

Gambar 8. Daftar Bengkel

Dari gambar 8, gambar daftar bengkel terdapat pilihan bengkel mobil yang disimbolkan dengan gambar mobil dan bengkel sepeda motor yang disimbolkan dengan gambar sepeda motor. Apabila tombol semua jenis bengkel dipilih maka akan muncul tampilan semua daftar bengkel baik dari jenis sepeda motor maupun bengkel mobil. Bengkel mobil apabila dipilih maka akan muncul tampilan sebagai berikut seperti pada Gambar 9, sedangkan bengkel sepeda motor apabila dipilih maka akan muncul tampilan sebagai berikut seperti pada Gambar 10.

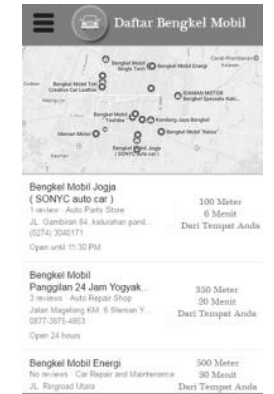

Gambar 9.

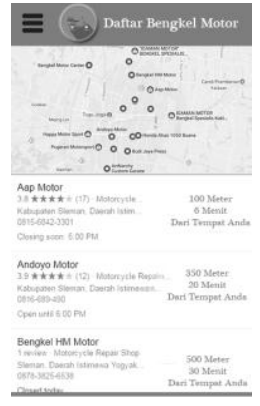

Gambar 10.

\section{Daftar Bengkel Mobil Daftar Bengkel Sepeda Motor}

Gambar 9 merupakan tampilan daftar bengkel mobil di Kabupaten Sleman, informasi yang disajikan dalam bentuk marker yang menyimpan informasi antara lain nama bengkel, alamat bengkel, gambar bengkel, nomor telepon, jarak dan waktu dan tempuh dari tempat pengguna pengendara berada. Gambar 10 merupakan tampilan daftar bengkel sepeda motor di Kabupaten Sleman, infomasi yang disajikan sama seperti daftar bengkel mobil. Apabila salah satu bengkel dipilih maka akan muncul tampilan seperti pada gambar 11 .

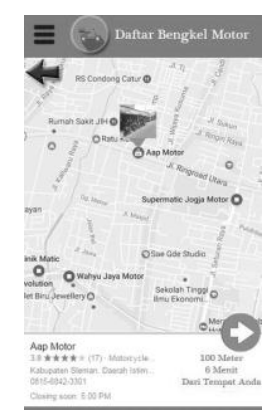

Gambar 11. Tampilan Peta Bengkel Sepeda Motor

Gambar 11 merupakan tampilan bengkel sepeda motor yang dipilih dari menu daftar bengkel sepeda motor dari gambar 10 diatas. Setelah bengkel dipilih maka akan muncul tampilan seperti pada Gambar 12 tentang marker lokasi bengkel dan jarak tercepat yang akan ditempuh jika pengendara berada di suatu tempat di mana pengendara mengalami kecelakaan yang menyebabkan kerusakan pada kendaraannya.

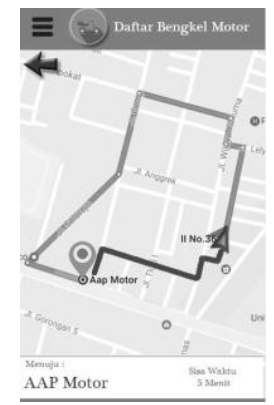

Gambar 12. Rute Jalan Tercepat menuju Bengkel Sepeda Motor

Skenario aplikasi mobile jika penegndara mobil bermasalah dan membutuhkan bengkel yang mempunyai mobil derek yaitu pengguna tinggal menekan nomor telepon yang tertera pada layar dari bengkel mobil yang terdapar simbol mobil derek. Berikut tampilan yang terdapat pada gambar 13 dibawah ini.

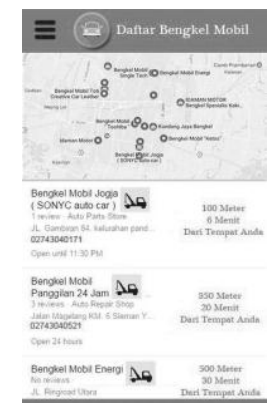

Gambar 13. Tampilan Bengkel Mobil Yang memiliki fasilitas Mobil Derek 
Dari gambar 13 diatas maka pengguna tinggal menekan nomor telepon yang ada dilayar sehingga akan muncul tampilan Phone sesuai smartphone yang diguanakn oleh pengguna, seperti pada gambar 14 dibawah ini.

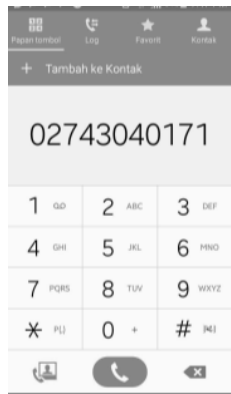

Gambar 14. Tampilan Tap Telepon Bengkel Mobil

\subsection{Antar Muka Pada Website}

Selanjutnya adalah tampilan admin yang berbasis website. Antarmuka admin yang pertama adalah tampilan login, form login seperti pada gambar 15 dibawah ini.

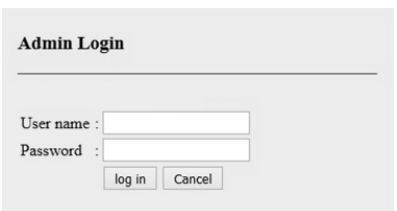

\section{Gambar 15. Tampilan Login Admin}

Gambar 15 merupakan tampilan login sebagai admin yang dibuka melalui website. Apabila aplikasi dijalankan tampilan yang pertama kali muncul adalah tampilan form login. Apabila login berhasil maka akan muncul antar muka beranda, antarmuka beranda seperti pada gambar 16 dibawah ini.

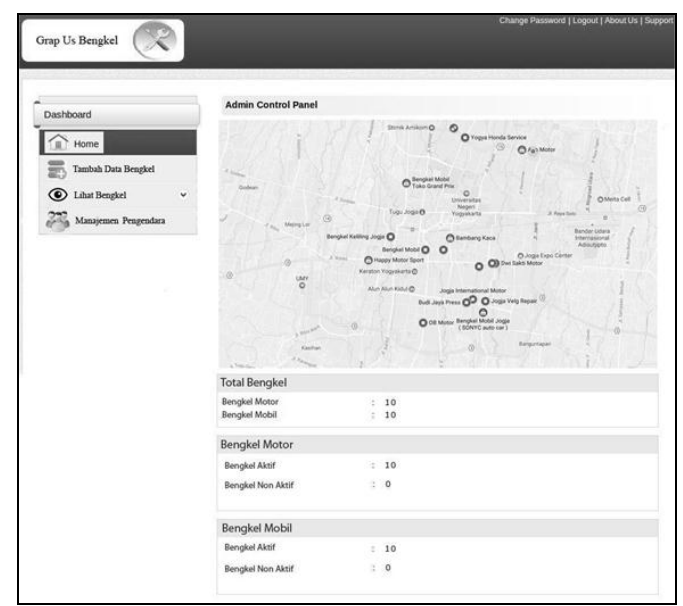

Gambar 16. Antarmuka Home Admin

Pada gambar 16, antar muka home admin muncul tampilan peta dan total bengkel mobil dan bengkel sepeda motor yang terdaftar. Pada kanan atas terdapat menu change password, logout, about us dan support. Terdapat menu Home (beranda), Tambah Data Bengkel, Lihat Bengkel dan Manajemen User. Pada menu Tambah
Data Bengkel apabila dipilih maka akan muncul tampilan seperti Gambar 13 dibawah ini.

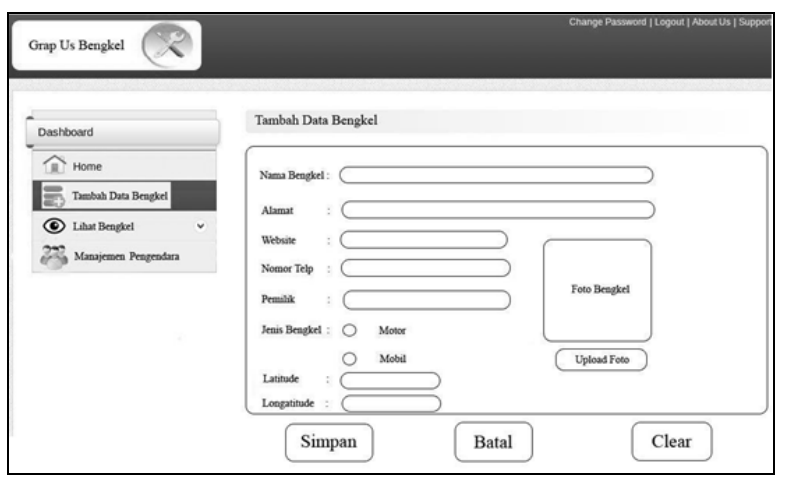

Gambar 17. Tambah Data Bengkel

Gambar 17 merupakan tampilan tambah data bengkel dengan form nama bengkel, alamat, website, nomor telepon, nama pemilik, foto bengkel, latitude dan longitude. Selanjutnya adalah menu Lihat Bengkel pada gambar 18 dibawah ini.

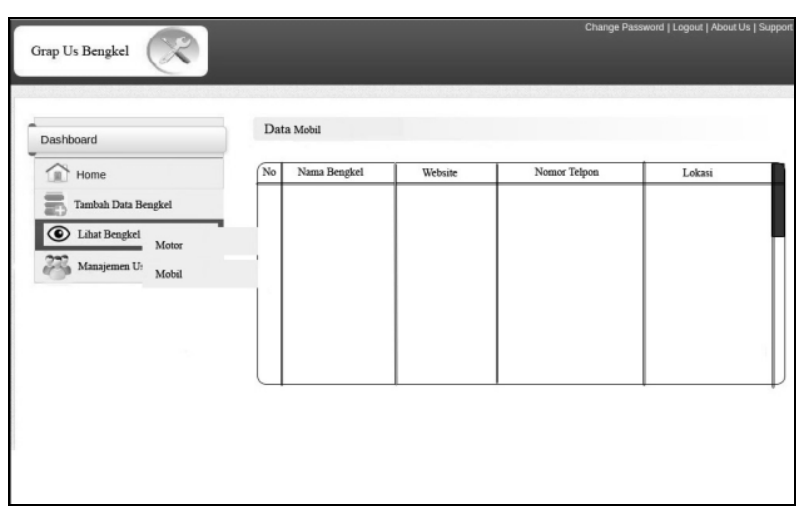

Gambar 18. Lihat Bengkel

Pada gambar 19 adalah menu lihat bengkel yang bersi daftar bengkel yang sudah terdaftar pada sistem. Gambar 20 dibawah ini merupakan tampilan manajemen pengendara yang berupa data pengendara yang melakukan registrasi lewat mobile.

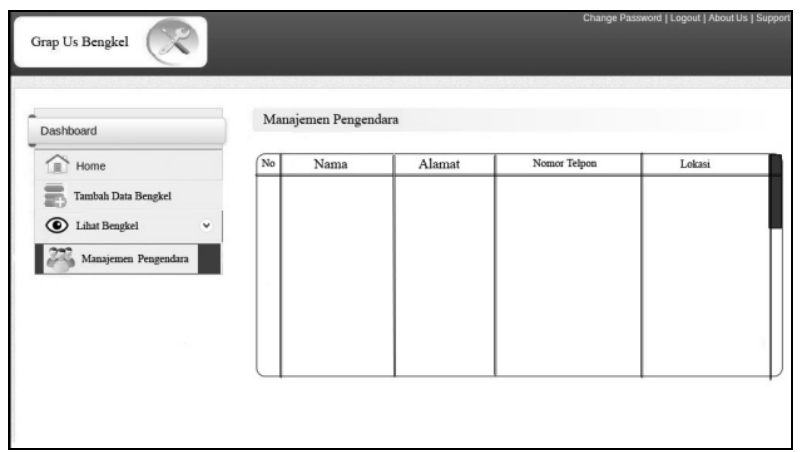

Gambar 20. Manajemen Pengendara

Dari gambar antar muka yang dijelaskan diatas, akan disajikan simulasi alur sistem dari segi mobile dan segi website. Berikut gambar 21 tentang simulasi alur dari segi mobile yang digunakan oleh pengendara yang akan mencari bengkel. 


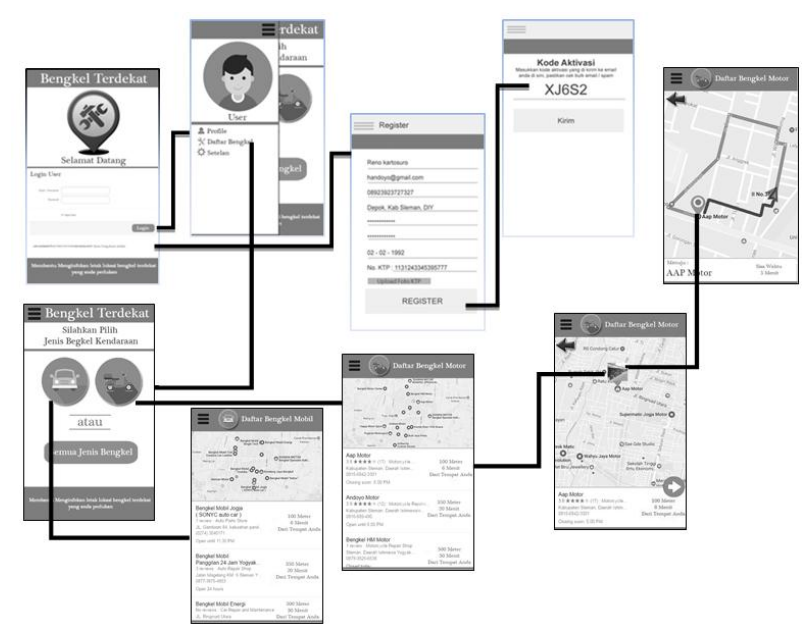

Gambar 21. Diagram Alur Pada Mobile

Berikut Gambar 22. simulasi alur dari segi website yang digunakan oleh pengguna admin.

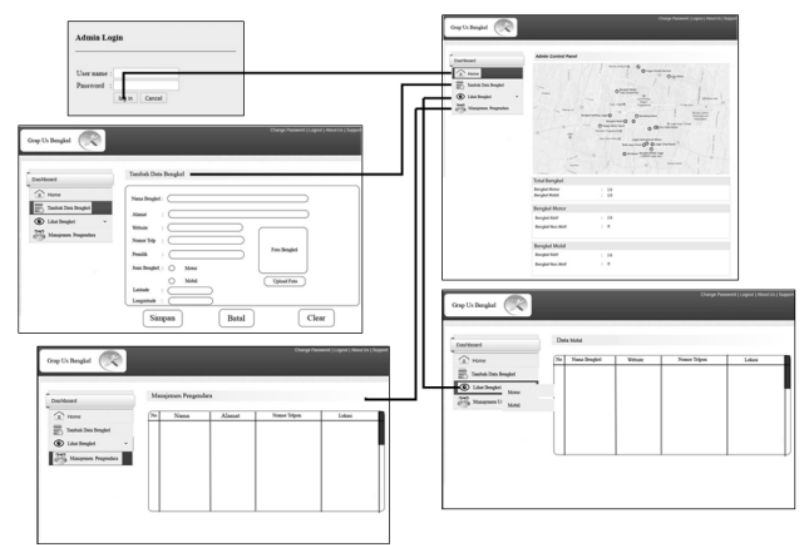

Gambar 22. Diagram Alur Pada Website

\section{Kesimpulan}

Perancangan antar muka Graph Us sebagai pemetaan bengkel di Kabupaten Sleman sebagai solusi pada masalah kecelakaan kendaraan bermotor berhasil memenuhi semua kebutuhan yang telah diidentifikasi pada tahap kebutuhan fungsional sistem yang digambarkan pada tabel 1 tentang kebutuhan fungsional sistem dan gambar 2 tentang use case diagram. Selain itu perancangan antar muka Graph Us menyajikan pengolahan data wilayah dan informasi bengkel dengan menampilkan marker pada tiap bengkel yang berada pada peta. Perancangan antar muka Graph Us memberikan informasi mengenai jalur tercepat menuju ke lokasi bengkel dengan dilengkapi fitur jalur menuju yang ditandai dengan warna merah berdasarkan arah jalan.

Meskipun demikian, aplikasi ini merupakan sistem yang dirancang secara sederhana perlu penambahan bengkel dari jenis kendaran lain, misal truk dan bus. Perlu adanya aplikasi yang lain dari masalah kecelakaan kendaraan bermotor agar solusi dari kerusakan kecelakaan tersebut dapat diintegrasikan ke sistem yang lebih kompleks.

\section{Daftar Pustaka}

[1] Ardani, Febri. Anda Tahu Populasi Kendaraan di Indonesia?. Kompas. Otomatif, tanggal akses 1 Desember 2016 pukul 15.00 WIB,http://otomotif.kompas.com/read/2016/08/20/103100215/An da.Tahu.Populasi.Kendaraan.di.Indonesia.

[2] Budi, Sufia. Angka Kecelakaan Lalu Lintas Di Indonesia Tertinggi Se Asia, tanggal akses 1 Desember 2016 pukul 15.15 WIB http://ragam.analisadaily.com/read/who-angka-kecelakaan-lalulintas-di-indonesia-tertinggi-se-asia/240063/2016/05/29

[3] Pemerintah Kabupaten Sleman. 2016. Dirjen Hubdar : Kondisi Sarana Transportasi di Sleman Banyak Yang Harus Dibenahi. Tanggal akses 16 Desember 2016 pukul 19.07 WIB http://www.slemankab.go.id/7324/dirjen-hubdar-kondisi-saranatransportasi-di-sleman-banyak-yang-harus-dibenahi.slm

[4] Sendow, T. K. \& Longdong Jefferson. Studi Pemetaan Peta Kota (Studi Kasus Kota Manado). Universitas Sam Ratulangi. Jurnal Ilmiah Media Engineering Vol. 2, No. 1, Maret 2012 ISSN 2087 9334 (35-46)

[5] Yuhana, Umi Laili, dkk. Pemanfaatan GoogleMaps Untuk Pemetaan Dan Pencarian Data Perguruan Tinggi Negeri Di Indonesia. Institut Teknologi Sepuluh Nopember. SISFO-Jurnal Sistem Informasi. Januari 2010,(21-26).

\section{Biodata Penulis}

Agustina Srirahayu, memperoleh gelar Sarjana Komputer (S.Kom), Jurusan Sistem Informasi STMIK Duta Bangsa Surakarta, lulus tahun 2015. Saat ini sedang melakukan studi lanjut Program Pasca Sarjana Magister Teknik Komputer STMIK AMIKOM Yogyakarta menjadi Staf pengajar di STMIK Duta Bangsa Surakarta.

Andrie Prajanueri Kristianto, memperoleh gelar Sarjana Komputer (S.Kom), Jurusan Teknik Informatika STMIK AMIKOM Yogyakarta, lulus tahun 2016. Saat ini sedang melakukan studi lanjut Program Pasca Sarjana Magister Teknik Komputer STMIK AMIKOM Yogyakarta.

Deden Hardan Gutama, memperoleh gelar Sarjana Komputer (S.Kom), Jurusan Sistem Informasi STMIK AMIKOM Yogyakarta, lulus tahun 2014. Saat ini sedang melakukan studi lanjut Program Pasca Sarjana Magister Teknik Komputer STMIK AMIKOM Yogyakarta.

Mahmudi, memperoleh gelar Sarjana Komputer (S.Kom), Jurusan Teknik Informatika STMIK Indonesia Banjarmasin, lulus tahun 2015. Saat ini sedang melakukan studi lanjut Program Pasca Sarjana Magister Teknik Komputer STMIK AMIKOM Yogyakarta.

Nendy Akbar Rozaq Rais, memperoleh gelar Sarjana Komputer (S.Kom), Jurusan Teknik Informatika Universitas Muhammadiyah Surakarta, lulus tahun 2015. Saat ini sedang melakukan studi lanjut Program Pascasarjana Magister Teknik Informatika (M.Kom) di STMIK AMIKOM Yogyakarta. 